\title{
Implementasi Nilai-Nilai Pendidikan Multikultural dalam Mata Kuliah Geografi Regional pada Jurusan Pips
}

\author{
Nur Cholifah
}

\author{
UIN Maulana Malik Ibrahim, Malang, Indonesia \\ Email: nurcholifah@uin-malang.ac.id
}

\author{
Tersedia Online di \\ http://www.jurnal.unublitar.ac.id/ \\ index.php/briliant
}

\begin{tabular}{l}
\hline Sejarah Artikel \\
\hline Diterima pada 29 Juli 2020 \\
Disetujui pada 19 Oktober 2020 \\
Dipublikasikan pada 30 \\
November 2020 \\
Hal. 710-720 \\
\hline
\end{tabular}

\section{Kata Kunci:}

Pendidikan karakter; Pendidikan multikultural; Geografi regional

\section{DOI:}

http://dx.doi.org/10.28926/briliant .$v 3 \mathrm{i} 4.528$

\begin{abstract}
Abstrak: Penguatan karakter menjadi salah satu tujuan utama dalam sistem pendidikan nasional. Penguatan karakter melalui pengembangan nilainilai pendidikan multikultural dalam pembelajaran dengan tujuan yaitu agar peserta didik mampu melihat kemajemukan dengan pemikiran terbuka, menerima dan menghargai perbedaan. Penanaman karakter diharapkan mampu mencetak generasi yang berpengetahuan dan memiliki karakter yang kuat. Penelitian ini menggunakan metode deskriptif dengan pendekatan kualitatif. Implementasi nilai multikultural pada pembelajaran matakuliah geografi regional meliputi tiga nilai karakter: demokratis, toleransi, dan kerjasama. Ketiga nilai tersebut mampu diterapkan oleh peserta didik dalam pembelajaran yang tercermin pada sikap saling menghargai perbedaan budaya, memberikan kesempatan berpendapat, bermusyawarah, dan penyatuan ide bersama
\end{abstract}

\section{PENDAHULUAN}

Pengembangan pendidikan karakter sangat erat kaitannya dalam pendidikan. Pengembangan diri seorang mahasiswa tidak hanya membutuhkan pengetahuan saja tetapi juga penguatan karakter yang diperlukan saat masa pendidikan berlangsung maupun sesudahnya. Kesuma dkk (2011) mengungkapkan bahwa penanaman karakter mempunyai tugas sebagai fasilitator dalam memperkuat dan mengembangkan nilai-nilai tertentu hingga tertanam dalam perilaku seorang anak yang mampu diterapkan tidak hanya saat berproses di sekolah tetapi juga lingkungan sekitarnya. Ilyas (2016) juga mengungkapkan bahwa Implementasi dalam pendidikan karakter adalah suatu proses yang tidak singkat, hal ini dikarenakan seorang anak bukan hanya diberikan pemahaman mengenai baik dan buruk saja tetapi juga menanamkan nilai-nilai arif dan luhur yang nantinya akan menjadi perilaku dalam diri seorang anak yang terwujud melalui kesehariannya.

Pendidikan karakter menjadi salah satu kunci utama dalam pergaulan anak baik di sekolah atau pun nanti setelah berada di lingkungan masyarakat. Apalagi dengan perkembangan zaman yang begitu pesat, pendidikan karakter menjadi salah satu bekal untuk anak dalam bergaul agar tidak terjerumus dalam hal yang kurang baik. Menilik pada pemberitaan di media banyak sekali perilaku yang kurang baik diakukan siswa kepada guru maupun anak terhadap orang tua. Hal tersebut menjadi satu masalah besar sekaligus memprihatinkan karena karakter anak yang kurang

710 BRILIANT: Jurnal Riset dan Konseptual Volume 5 Nomor 4, November 2020 
terbentuk dengan baik.

Pergaulan yang semakin bebas menjadi salah satu pengaruh yang memberikan dampak cukup besar terhadap karakter yang dimiliki oleh seorang anak. Apalagi dengan mudahnya akses komunikasi dan jaringan internet, tidak hanya pengetahuan atau pemberitaan yang baik tetapi juga hal-hal yang kurang sesuai dapat diakses dengan mudah oleh anak. Imbasnya ketika anak sering mengakses hal yang tidak sesuai dengan usia atau konten yang kurang mendidik dapat membuat karakter seorang anak yang harusnya baik dan berkembang menjadi terganggu dan timbullah ketidak sesuaian perilaku yang ditunjukkan dalam kehidupan sehari-hari. Menurut Aheniwati (2019) fase terburuk seorang anak yang sudah kecanduan gadget adalah ketidak peduliannya terhadap keluarga dan lingkungan sekitar. Ketidak pedulian terhadap lingkungan inilah yang membuat anak bersikap anti sosial, mementingkan diri sendiri, dan kurang peduli terhadap kepentingan orang sekitar. Dampak panjang yang bisa timbul yaitu egoisme yang membuat kurang rasa toleran atau menghargai antar sesama. Sikap kerjasama yang seharusnya ada pada anak yang mampu dipraktekkan dalam lingkungan masyarakat pun hilang karena kurangnya sikap sosial yang dimiliki oleh seorang anak.

Pengaruh besar ditunjukkan ketika anak sudah memiliki perubahan perilaku terhadap sudut pandang adanya perbedaan. Sebuah perbedaan harusnya dapat mempererat rasa persaudaraan antar sesama, saling menghargai, dan menimbulkan rasa syukur karena hidup dalam lingkungan multikultur. Akan tetapi, respon yang diberikan oleh sebagian besar orang khususnya kalangan remaja sudah berbeda. Sekarang ini banyak orang yang kurang memiliki keterbukaan terhadap adanya perbedaan dan sering kali perbedaan dianggap pemicu timbulnya satu perdebatan. Pemikiran seperti itulah yang menyebabkan munculnya banyak kasus "bullying" dan juga kerusuhan yang sangat meresahkan masyarakat. Banyak kasus yang telah tersiar melalui media adanya tawuran antar warga karena memperebutkan wilayah dan perkelahian antar siswa sekolah yang terjadi di beberapa daerah. Hal tersebut tidak seharusnya terjadi apabila sikap saling memahami dan menghargai terbentuk dengan baik pada setiap individu. Kejadian seperti ini akan semakin parah apabila tidak dibarengi dengan adanya penanaman karakter pada anak, terutama di bidang pendidikan. Demoralisasi terjadi salah satunya karena pembelajaran mengenai moral hanya sebatas teks dan kurang mempersiapkan siswa menghadapi kehidupan yang lebih kompleks (Koni, 2016). Oleh sebab itulah, amat penting menanamkan karakter pada anak sejak usia dini, terutama di sekolah.

Penanaman karakter bertujuan untuk membentuk akhlaq anak sejak usia dini terutama usia remaja. Wajdi (2010) menyebutkan bahwa penting bagi anak remaja mendapatkan pendidikan karakter untuk membantu mengenal karakternya karena usia remaja adalah masa tumbuh kembang dan terkadang pula labil. Penanaman karakter khususnya yang terdapat dalam pendidikan multikultural penting untuk diajarkan kepada anak, sehingga anak bisa menghargai dan mampu bersikap toleran terhadap perbedaan dan menghargai sesama di lingkungan sekitar. Selain di lingkungan sekitar pendidikan multikultural juga perlu ditanamkan oleh guru kepada peserat didik di setiap pembelajaran.

Penelitian yang telah dilakukan oleh Sri Wulandari Danoebroto (2012) dengan judul Model Pembelajaran Matematika Berbasis Pendidikan Multikultural. Kegiatan pembelajaran dilakukan dengan mengintegrasikan nilai-nilai multikultur dilakukan dengan mengembangkan integrasi konten yang dieksplorasi dari 
kekayaan budaya daerah, menggunakan konteks multikultur dalam mengilustrasikan konsep atau prinsip matematika. Penelitian tentang pendidikan multikultural juga pernah dilakukan oleh Ahmad Noor Fida (2016) dengan judul Implementasi Pendidikan Multikultural dalam Pembelajaran Sosiologi SMA. Berdasar pada hasil yang telah diperoleh bahwa penerapan pendidikan multikultural dalam mata pelajaran sosiologi sangat relevan dengan materi pembelajaran. Penerapan pendidikan multikultural dalam mata pelajaran sosiologi diharapkan mampu menjadikan peserta didik dalam hal ini siswa SMA Negeri 3 Klaten dapat mempunyai karakter yang baik dan kuat sesuai dengan visi, misi, dan tujuan sekolah.

Penelitian terdahulu yang telah dilakukan merupakan salah satu bukti bahwa sekolah merupakan salah satu wadah yang tepat untuk menanamkan karakter pada anak. Guru memberikan penanaman karakter melalui proses pembelajaran. Peserta didik tidak hanya mendapatkan kemampuan dalam pengetahuan saja tetapi juga pembentukan akhlaq yang bisa diterapkan saat dan setelah pendidikan di sekolah selesai. Penelitian ini mencoba menunjukkan deskripsi kegiatan implementasi pendidikan karakter yang berkaitan dengan nilai-nilai pendidikan multikultural dalam pembelajaran geografi regional. Nilai-nilai pendidikan multikultural dapat muncul didalamnya karena keanekaragaman yang begitu tampak jelas dari setiap region yang dibahas. Tujuan utama dalam implementasi pendidikan multikultural pada pembelajaran mata kuliah geografi regional agar peserta didik mampu melihat kemajemukan dengan pemikiran terbuka, menerima perbedaan dan menghargai sesama yang nantinya mampu diterapkan dalam kehidupan sehari-hari.

\section{METODE}

Penelitian ini menggunakan metode deskriptif dengan pendekatan kualitatif. Bogdan dan Taylor (Moleong, 2007) menyebutkan bahwa penelitian kualitatif menghasilkan data yang berupa deskriptif (kata tertulis, ucapan, atau perilaku dari orang yang dapat diamati). Subjek penelitian yaitu kelas D semester VI jurusan PIPS UIN Maulana Malik Ibrahim Malang sebanyak 36 mahasiswa. Penelitian ini mendeskripsikan hasil dari penelitian dengan menggambarkan keadaan yang ada di lapangan berdasar pada hasil observasi langsung kegiatan mahasiswa selama pembelajaran. Analisis yang digunakan yaitu model Analysis interactive dari Miles and Huberman (1994), analisis ini terbagi dalam beberapa kegiatan yaitu: kegiatan dimulai dari mengumpulkan data, selanjutnya data direduksi kemudian penyajian data (dalam bentuk tabel, grafik, atau deskripsi) dan terakhir tahap penarikan kesimpulan atau verifikasi data. Pada penelitian ini data diperoleh dengan metode observasi secara langsung pada subjek penelian. Observasi dilakukan untuk melihat respon mahasiswa dalam pembelajaran.

\section{HASIL DAN PEMBAHASAN}

\section{Nilai-Nilai Pendidikan Multikultural}

Multikultural erat kaitannya dengan masyarakat majemuk dengan keanekaragaman atau perbedaan yang besar baik dari unsur budaya, suku, dan bahasa. Keanekaragaman itulah yang menjadikan satu keunikan tersendiri karena ada yang mampu menerimanya atau mungkin kurang mampu untuk menanggapinya dengan pemikiran yang lebih sederhana. Keanekaragaman pun dianggap menjadi satu hal yang menjadikan satu karena dilihat dari sudut pandang bahwa beda itu

712 BRILIANT: Jurnal Riset dan Konseptual

Volume 5 Nomor 4, November 2020 
adalah anugerah Tuhan yang harus dihormati dalam setiap aspeknya agar tercipta suatu kedamaian. Seperti yang diungkapkan Wibowo (2010) Multikulturalisme mengutamakan pentingnya mengakui dan bersikap saling menghargai terhadap adanya keragaman budaya dan mengubah kebijakan publik untuk megakomodasi keragaman yang bertujuan agar tercipta masyarakat yang adil dan damai. Multikultural pun kini telah masuk dalam dunia pendidikan, nilai-nilainya diterapkan dalam pembelajaran guna untuk menumbuhkan karakter yang mampu menerima adanya beda atau ketidak samaan antara satu dengan yang lainnya. Selain itu, penerapan pendidikan multikultural di sekolah diharapkan peserta didik mendapatkan kesempatan dan pilihan untuk mendukung dan memperhatikan satu atau beberapa budaya, seperti halnya bahasa, sistem nilai, dan gaya hidup (Hanafy, 2015).

Konsep pendidikan multikultural pun beragam yang semua terpatok pada sikap mampu merima perbedaan. Mania (2010) berpendapat bahwa Pendidikan multikultural merupakan suatu bentuk pendidikan yang berbasis pada pemanfatan keragaman yang ada di masyarakat terutama yang ada pada diri siswa mulai dari bahasa, etnis, budaya, gender, status sosial, ras, umur, dan kemampuan yang dimiliki siswa. Keberagaman itulah yang dijadikan strategi dan konsep dalam pendidikan multikultural. Tujuan utama dari strategi tersebut untuk meningkatkan kemampuan siswa dalam berperilaku pluralis, humanis, dan demokratis. Sementara itu Sonia Nieto (2002) menyatakan bahwa pendidikan multikultural disebut juga dengan pendidikan yang memiliki proses komprehensif dan dasar bagi anak didik. Pembelajarannya mengutamakan pada penerimaan terhadap perbedaan, menguatkan pluralitas dan menentang adanya rasisme dan diskriminasi di sekolah maupun masyarakat yang terefleksikan antara guru, komunitas, dan anak didik.

Pendidikan multikultural memiliki nilai-nilai utama dalam penerapan di pembelajaran. Seperti menurut Dawam (2003) pendidikan multikultural memiliki tujuh poin penting yaitu: Kesatu, orientasi kemanusiaan (Humanisme), yaitu bersifat universal dan global (tanpa memandang perbedaan suku, ras, golongan dan agama). Kedua, berorientasi pada kebersamaan, diartikan bahwa tidak akan ada pihak yang dirugikan atas dibangunnya sebuah kebersamaan. Ketiga, berorientasi pada kesejahteraan (welvarisme), diartikan bukan mengenai banyaknya kebutuhan yang terpenuhi atau sama besar akan tetapi masyarakat dengan sadar dan tanpa paksaan mengakui bahwa dirinya telah sejahtera. Keempat, berorientasi pada kedamaian (peacevisme), damai dapat tercipta ketika mampu memenuhi kebutuhan dasar, merasa aman, dihargai, diakui, dan mendapat perlakuan yang sama dari setiap orang yang diajak berinteraksi dengannya. Kelima, orientasi proporsional, yaitu ketepatan makna dari sebuah nilai ditinjau dari berbagai sudut pandang pemikiran. Keenam, berorientasi pada pengakuan terhadap pluralitas dan heterogenitas. Ketujuh, berorientasi pada anti hegemoni dan anti dominasi pada seluruh bidang yang berkaitan dengan masyarakat.

Nilai pendidikan multikultural yang akan diimplementasikan pada penelitian ini diambil dari jabaran nilai-nilai yang diutarakan oleh Mania dan Dawam. Nilai-nilai pendidikan multikultural yang ada dari dua pendapat tersebut dipilah dan disesuaikan dengan kegiatan dan materi yang akan dilakukan. Berdasar pada penyesuaian materi dan kegiatan yang akan dilakukan maka implementasi nilai pendidikan multikultural pada mata kuliah geografi regional diambil tiga penilaian yaitu demokratis, toleransi, dan kerjasama. Ketiga nilai inilah nanti yang 
kan menjadi fokus utama dalam penerapan pendidikan multikultural dalam kegiatan pembelajaran.

\section{Pembelajaran Geografi Regional}

Geografi regional adalah satu diantara beberapa mata kuliah dalam bidang ilmu geografi yang ada di Jurusan Pendidikan Ilmu Pengetahuan Sosial yang membahas tentang karakteristik kehidupan di berbagai macam wilayah di dunia. Ruang lingkup geografi regional yaitu pembahasan keterkaitan lingkungan fisik dan manusia. Dijabarkan ke dalam sebuah kalimat yaitu variasi penyebaran gejala di dalam ruang di lokasi spesifik baik secara lokal, negara, dan benua. Area lingkup geografi regional mencakup seluruh gejala di lokasi yang terkait baik gejala fisik maupun manusia. Menurut Preston R. James \& Nelda Davis (Marhadi, 2019) bidang keilmuan yang membahas tentang kenampakan dalam suatu tempat tertentu yang saling berkaitan atau saling berasosiasi. Hubungan timbal balik yang terjadi antara manusia dengan alam atau lingkungan inilah nanti akan menciptakan satu hal baru seperti budaya, pekerjaan, sosial, politik dan lain sebagainya.

Pembelajaran geografi regional memiliki indikator untuk dicapai peserta didik yang menempuh mata kuliah ini. Indikator tersebut yaitu mahasiswa diharapkan mampu mengetahui potensi-potensi fisik maupun non fisik suatu wilayah, permasalahan lokal, regional, maupun global dalam kaitannya dengan peristiwa sosial, politik, ekonomi, budaya, maupun yang lainnya. Selain itu, geografi regional memberikan pengetahuan baru tentang wilayah yaitu (Marhadi, 2019): pertama, memberikan Informasi tentang potensi suatu negara baik sumber daya fisik maupun non fisik yang ada kaitan dengan kelangsungan kehidupan penduduknya. Kedua, memberikan informasi sumber-sumber penyebab konflik dalam suatau negara. Ketiga, memberikan informasi tentang latar belakang adanya pengelompokan negara-negara di dunia dalam aliansi tertentu baik dalam bentuk kerja sama bilateral,regional, internasional, baik di bidang ekonomi, perdangan, politik, atau pertahanan. Keempat, memberikan informasi perubahan peta peta politik dari suatu negara dari aspek waktu dan ruang. Pada pembelajaran geografi regional peserta didik juga bisa memperoleh informasi ragam kebudayaan yang ada dalam satu wilayah atau region tertentu baik dari persamaan amaupun perbedaannya.

Mata kuliah geografi regional memiliki satu keterkaitan terhadap penerapan pendidikan multikultural. Keterkaitan dapat dilihat dari penjelas Mania dan Dawam mengenai pendidikan multikultural yang mengedepankan nilai-nilai multikultur dan dipadukan dengan pembelajaran geografi regional yang membahas mengenai keberagaman karakteristik yang dimiliki oleh negara-negara di dunia. Ketepatan materi ajar yang membahas mengenai berbagai macam karakteristik negara-negara di dunia dan penerapan nilai-nilai multikultur diharapkan dapat membuka pemikiran peserta didik mengenai keberagaman. Nilai karakter yang telah dipelajari diharapkan dapat diterapkan oleh peserta didik dalam pergaulan sehari-hari di kampus maupun di lingkungan tempat tinggalnya.

\section{Implementasi Nilai-Nilai Pendidikan Multikultural dalam Pembelajaran Geografi Regional}

Nilai-nilai pendidikan multikultural terdapat dalam pembelajaran geografi regional. Pembelajaran ini membahas tentang keragaman fisik dan non fisik suatu

714 BRILIANT: Jurnal Riset dan Konseptual

Volume 5 Nomor 4, November 2020 
wilayah. Kemajemukan aspek fisik dan non fisik dipelajari peserta didik yang dapat menunjukkan bahwa dunia ini begitu beragam dengan karakteristik masing-masing. Melalui keragaman inilah peserta didik belajar menanamkan nilai-nilai multikultural dalam dirinya sebagai satu karakter yang baik untuk dikembangkan. Nilai dari pendidikan multikultural dapat membuka pemikiran peserta didik untuk bersikap terbuka dan tidak anti dengan adanya perbedaan. Pada jabaran kurikulum, pendidikan multikultural diharapkan mampu mengakomodasi perbedaan budaya dan memanfaatkannya agar budaya tersebut bisa berkembang, mengajarkan nilai toleransi, pengembangan pribadi etis, pemahaman terhadap perbedaan, sehingga mampu membangkitkan semangat kebhinekaan. Kebudayaan dalam diri anak didik juga mampu dimanfaatkan sebagai entry behavior yang nantinya dapat dijadikan sebagai kunci agar anak didik mampu menciptakan prestasi yang sama dalam pendidikan (Jaya, 2013).

Pendidikan multikultural menjadi satu acuan baru agar peserta didik memahami arti sebuah perbedaan. Adanya beda bukan untuk dijauhi atau diacuhkan tetapi untuk dipahami dan disejajarkan satu sama lainnya. Multikultural tidak bisa dihindari oleh seluruh manusia, sehingga kenyataan adanya perbedaan harus diterima dan kultur yang berbeda-beda tidak menyebabkan pecah belah atau saling memusuhi satu sama lain (Sapendi, 2015). Kemajemukan pun telah dibahas dalam Al-Qur'an yang terdapat pada Al-Qur'an surat Al-Hujurat:13, bunyi terjemahannya

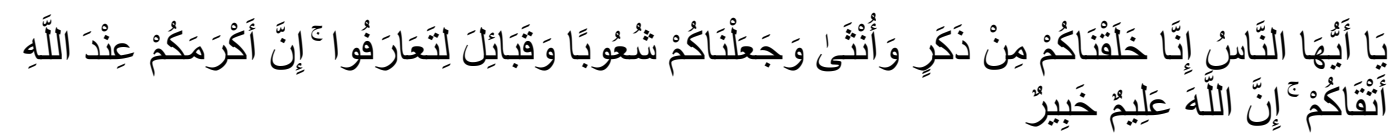

Artinya:

Hai manusia, Sesungguhnya Kami telah menciptakan kamu dari seorang laki-laki dan seorang perempuan dan menjadikan kamu berbangsa-bangsa dan bersuku-suku supaya kamu saling mengenal. Sesungguhnya orang yang paling mulia diantara kamu disisi Allah ialah orang yang paling taqwa diantara kamu. Sesungguhnya Allah Maha mengetahui lagi Maha Mengenal.

Beradasar pada tafsir ayat Al-Qur'an di atas dapat diketahui bahwa Allah SWT telah menciptakan laki-laki dan perempuan, bangsa-bangsa atau suku-suku yang berbeda, sehingga semuanya bisa saling mengenal. Perbedaan ada untuk dipahami dan dikenali satu sama lainnya agar dapat berbaur menjadi satu dan tidak untuk diacuhkan apalagi terjadi diskriminasi. Perbedaan merupakan rahmat dari Allah SWT yang harus disyukuri oleh semua orang karena penilaian Allah dari setiap orang dilihat dari ketakwaannya. Tafsir ayat di atas apabila dikaitkan dengan masyarakat heterogen, dapat disimpulkan bahwa setiap lapisan masyarakat memiliki fungsinya masing-masing didalam hubungan sosial. Dimulai pada skala kecil yaitu hubungan antar keluarga sampai skala besar seperti antar kelompok yang berkaitan dengan keragaman etnis, budaya, dan agama memiliki peranan dalam membangun kebersamaan untuk mewujudkan satu eksistensi bersama. Begitu pula dengan diri individu juga memiliki peranan penting untuk terwujudnya kebersamaan (Munawar \& Halim, 2005).

Paparan kegiatan dan nilai pendidikan multikultural yang dicapai oleh peserta didik dalam implementasi pendidikan multikultural sebagai berikut: 
Tabel 1 Paparan kegiatan dan capaian peserta didik

\begin{tabular}{|c|c|c|}
\hline $\begin{array}{l}\text { Nilai Pendidikan } \\
\text { Multikultural }\end{array}$ & Kegiatan Pembelajaran & Capaian Peserta Didik \\
\hline Demokratis & Diskusi & $\begin{array}{l}\text { - Memberi kesempatan } \\
\text { bertanya secara adil } \\
\text { - Menghargai pendapat teman } \\
\text { dalam berdiskusi } \\
\text { - Keterbukaan terhadap } \\
\text { perbedaan pendapat } \\
\text { - Memberikan jawaban dan } \\
\text { menyanggah secara sopan } \\
\text { dan tutur bahasa yang baik }\end{array}$ \\
\hline Toleransi & 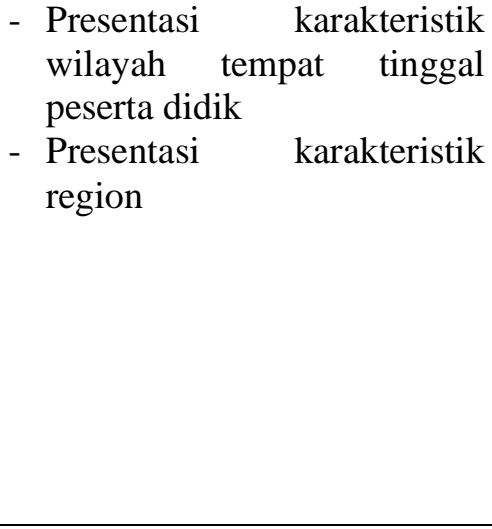 & $\begin{array}{l}\text { - Memberikan pertanyaan } \\
\text { yang bersifat solutif } \\
\text { mengenai permasalahan di } \\
\text { daerah pemateri } \\
\text { - Pertanyaan tidak ada yang } \\
\text { bersifat menjatuhkan } \\
\text { - Memberikan respon positif } \\
\text { mengenai kearifan lokal } \\
\text { yang ada di daerah pemateri } \\
\text { - Tidak membandingkan } \\
\text { antara karakteristik daerah } \\
\text { pemateri dengan yang lain }\end{array}$ \\
\hline Kerjasama & $\begin{array}{l}\text { - Diskusi } \\
\text { - Penyelesaian makalah dan } \\
\text { PPT untuk presentasi }\end{array}$ & $\begin{array}{l}\text { - Dalam satu kelompok } \\
\text { saling membatu untuk } \\
\text { menjawab pertanyaan dan } \\
\text { sanggahan yang diberikan } \\
\text { oleh audiens } \\
\text { - Menyelesaikan makalah } \\
\text { dan PPT yang dijadikan } \\
\text { bahan presentasi. } \\
\text { - Tidak mendominasi dalam } \\
\text { mempresentasikan } \\
\text { makalah dan menjawab } \\
\text { pertanyaan dari audiens }\end{array}$ \\
\hline
\end{tabular}

Nilai demokratis dalam pendidikan multikultural pada proses pembelajaran geografi regional tercermin ketika peserta didik melakukan diskusi dari berbagai tema yang telah ditentukan. Implementasi nilai demokratis terlihat ketika pemateri memberikan waktu untuk audiens bertanya dan menyanggah tanpa adanya paksaan dan intervensi dari anggota pemateri maupun dari audiens yang lainnya. Memberikan kesempatan pada audiens dengan cara menunjuk secara acak dan dipilih secara objektif. Penggunaan bahasa yang sopan dan santun dalam memberikan jawaban dan sanggahan. Sikap saling menghargai pendapat orang lain dan memberikan kesempatan berbicara dalam sebuah forum diskusi tersebut merupakan salah satu wujud dari sikap demokratis. Chayati dan Supriyanto (2015) menyatakan bahwa penanaman jiwa demokratis bisa juga diimplementasikan melalui studi sosial dengan cara mengajak siswa untuk menghargai pendapat orang lain, mampu bersikap wajar dengan adanya perbedaan pendapat, bersikap jujur,

716 BRILIANT: Jurnal Riset dan Konseptual Volume 5 Nomor 4, November 2020 
mengedepankan sikap keterbukaan, dan mampu membuat kesepakatan bersama demi mencapai sebuah kesepahaman. Sikap demokratis yang ditunjukkan oleh peserta didik sesuai dengan konsep nilai pendidikan multikultural yang diutarakan oleh Dawam yaitu terciptanya kedamaian dalam kelas. Kedamaian yang dimaksud adalah peserta didik merasa dihargai, diakui keberadaannya, memperoleh perilaku adil, dan diberikan kesempatan untuk ikut serta dalam diskusi di dalam kelas.

Nilai toleransi atau menghargai adanya keragaman budaya dalam pendidikan multikultural pada proses pembelajaran geografi regional tercermin ketika peserta mempresentasikan salah satu wilayah tempat tinggalnya. Mahasiswa yang dibagi kedalam kelompok, satu kelompok berjumlah tiga orang, mempresentasikan salah satu daerah tempat tinggal dari anggotanya dan menjelaskan mengenai karakteristik, pengembangan wilayah, dan permasalahan yang terdapat di daerah tersebut. Pada tahapan ini pembelajaran tetap dilakukan dengan diskusi, peserta didik melakukan tanya jawab mengenai daerah yang telah dijelaskan oleh presenter. Pada saat proses diskusi berlangsung, pertanyaan dan saran yang diberikan dalam diskusi cenderung mengarah pada solusi untuk pengembangan daerah dan kelestarian budaya. Peserta didik menanggapi dengan positif terkait budaya yang berbeda antar daerah dan tidak membandingkan satu dengan yang lainnya. Sikap tidak membandingkan atau membedakan yang tumbuh dari peserta didik adalah satu cerminan bahwa perbedaan ada untuk dihargai dan dihormati. Kesadaran diri dari peserta didik bahwa dalam bermasyarakat harus mampu hidup berdampingan dengan adanya perbedaan. Rahmawati dan Fatmawati (2016) menyatakan bahwa sekolah merupakan lingkungan yang heterogen dikarenakan banyak peserta didik yang datang dari berbagai macam latar belakang yang punya satu tujuan yaitu belajar bersama. Sikap toleransi memiliki andil yang cukup besar dalam menghargai perbedaan dan menumbuhkan kebersamaan diantara peserta didik.

Nilai toleransi dan kerjasama terdapat pada saat penyampaian materi inti yang disampaikan oleh peserta didik mengenai karakteristik realm yang ada di dunia. Peserta didik (audien) saling mengajukan pertanyaan dan terjadi diskusi antara pemateri dan audien. Berdasar dari hasil observasi, peserta didik banyak berdiskusi mengenai keragaman yang dimiliki oleh suatu negara. Peserta didik banyak bertanya mengenai perbedaan antara negara satu dengan yang lain yang terdapat dalam suatu realm. Selain itu, ada pula yang menanyakan bagaimana terbentuknya suatu realm dan alasan suatu negara bergabung dalam satu realm tertentu. Pembelajaran yang bisa diperoleh dari hasil diskusi ini selain mengenai karakteristik yang dimiliki oleh negara-negara dalam satu realm yaitu nilai kebersamaan dalam kemajemukan. Perbedaan karakteristik dan budaya yang dimiliki oleh negara satu dengan yang lain tidak menghalangi adanya kerjasama dan kerukunan yang terbangun dengan baik dalam satu realm. Nilai toleransi yang dikembangkan dalam pembelajaran geografi regional ini sesuai dengan perintah Allah SWT dalam Al-Qur'an surat Al-Hujurat: 13 bahwa Allah SWT menciptakan manusia berbangsa-bangsa dan bersuku-suku dan sudah sepatutnya antar manusia saling mengenal dan menghargai. Sikap toleransi juga terdapat dalam nilai multikultural yang dijelaskan oleh Dawam yaitu sikap humanisme yang artinya pandangan global atau universal terhadap satu keberagaman. Selain itu, Dawam juga menyebutkan bahwa salah satu kriteria penerapan pendidikan multikultural adalah berorientasi pada pengakuan terhadap pluralitas dan heterogenitas yang 
artinya mampu menerima adanya keberagaman atau memiliki rasa toleran terhadap sesama. Mania juga menjelaskan bahwa memiliki sikap toleransi adalah salah satu tujuan pembelajaran pendidikan multikultural.

Nilai kerjasama terwujud saat peserta didik mampu menyelesaikan pembuatan makalah dan diskusi. Kerjasama yang dimaksudkan adalah kemampuan menyatukan pemikiran satu sama lain yang tertuang dalam satu makalah dan mempresentasikan hasil kerja yang telah dibuat. Peserta didik mampu bekerja sama dalam proses diskusi yaitu menjawab dan saling memberikan argumen terhadap pertanyataan yang diajukan oleh audiens. Nilai kerjasama pada proses pembelajaran dilakukan oleh dua atau lebih peserta didik yang saling berinteraksi satu sama lainnya, menggabungkan tenaga, merangkai ide atau pendapat menjadi satu dalam waktu tertentu untuk mencapai tujuan pembelajaran yang telah ditentukan sebagai kepentingan bersama (Yulianti et al., 2016). Proses kerjasama yang dilakukan oleh peserta didik baik dalam pembuatan makalah maupun diskusi menunjukkan bahwa adanya sikap saling menghargai dan menghormati ide orang lain dan disatukan ke dalam ide bersama untuk menyelesaikan tugas pembuatan makalah dan diskusi. Nilai kebersamaan yang diterapkan dalam pembelajaran geografi regional ini sesuai dengan konsep nilai pendidikan multikultural yang disebutkan oleh Dawam yaitu sikap kebersamaan yang artinya saling bergotong royong menyelesaikan permasalahan dan semua pihak tidak ada yang dirugikan dalam menjalin satu kesepakatan dan kebersamaan.

\section{KESIMPULAN}

Pengembangan karakter peserta didik pada pembelajaran geografi regional dibentuk dengan penerapan nilai-nilai pendidikan multikultural. Nilai pendidikan multikultural yang diterapkan pada pembelajaran geografi regional diantaranya yaitu demokratis, toleransi, dan kerjasama. Implementasi nilai multikultural pada pembelajaran matakuliah geografi regional di kelas D jurusan PIPS UIN Maulana Malik Ibrahim Malang dilakukan dengan menerapkan unsur-unsur pendidikan multikultural saat diskusi dan presentasi materi tema tambahan dan utama. Pada saat proses pembuatan makalah, diskusi, hingga presentasi dapat dilihat bahwa peserta didik mampu menerapkan sikap yang berkaitan dengan nilai-nilai multikultural seperti menghargai pendapat, penyatuan ide bersama, musyawarah, dan memberikan kesempatan untuk berpendapat tanpa menyudutkan atau intervensi dari kelompok atau teman sekelas. Sikap inilah yang ingin ditumbuhkan dalam pembelajaran geografi regional, sehingga mampu meningkatkan kemampuan peserta didik dalam memaknai suatu kemajemukan dengan pemikiran terbuka dan menumbuhkan rasa kebersamaan untuk menciptakan generasi yang lebih baik dari segi pengetahuan dan toleransi terhadap keberagaman.

\section{SARAN}

Saran untuk implementasi pendidikan multikultural pada mata kuliah geografi regional agar lebih memperbanyak tema diskusi yang berkaitan dengan daerah masing-maisng peserta didik, sehingga penanaman nilai pendidikan multikultural lebih mendalam. Pengembangan nilai multikultural sebaiknya tidak hanya nilai demokratis, toleransi, dan kebersamaan saja tetapi bisa ditambahkan dengan nilai pendidikan multikultural yang lain, sehingga peserta didik akan

718 BRILIANT: Jurnal Riset dan Konseptual Volume 5 Nomor 4, November 2020 
semakin memahami mengenai pendidikan multikultural. Pada akhir pembelajaran akan lebih baik lagi kalau peserta didik bisa membuat satu media pembelajaran yang berkaitan dengan kemajemukan dan kerjasama yang ada di Indonesia maupun di tiap region yang ada di dunia. Adanya media ini nanti diharapkan mampu memberikan gambaran pada peserta didik bahwa kemajemukan yang ada di lingkungan sekitar maupun seluruh dunia mampu menumbuhkan rasa kerukunan dan saling menghargai. Peserta didik juga bisa menggunakan media yang telah dibuat bersama sebagai bekal yang dapat digunakan pada pembelajaran di kelas ketika nanti menjadi seorang pendidik atau pada saat praktik mengajar di sekolah.

\section{DAFTAR RUJUKAN}

Aheniwati. (2019). Pengaruh Internet Bagi Anak. Jurnal Edukasia, 6(2), 8.

Chayati, N., \& Supriyanto, E. (2015). Pengelolaan Pembelajaran Sikap Demokratis di SMP Muhammadiyah 1 Kartasura. Jurnal Pendidikan Sosial, 25(2), 14.

Danoebroto, S. W. (2012). Model Pembelajaran Matematika Berbasis Pendidikan Multikultural. Jurnal Pembangunan Pendidikan: Fondasi dan Aplikasi, 1(1), 14.

Dawam, A. (2003). "Emoh" sekolah: Menolak" komersialisasi pendidikan" dan " kanibalisme intelektual”, menuju pendidikan multikultural. Inspeal Ahimsakarya Press.

Fida, A. N., Pd, S., \& Pd, M. (2016). Implementasi Pendidikan Multikultural Dalam Pembelajaran Sosiologi SMA. Jurnal PPKn \& Hukum, 11(2), 20.

Hanafy, M. S. (2015). Pendidikan Multikultural dan Dinamika Ruang Kebangsaan. Jurnal Diskursus Islam, 3(1), 21.

Ilyas. (2016). Pendidikan Karakter Melalui Homeschooling. Journal of Nonformal Education, 2(1), 91-98.

Jaya, E. (2013). Pendidikan Multikultur: Membangun Keberagaman Inklusif dan Moderat di Kalimantan Barat. Jurnal Khasanah Pendidikan, 2(1), 8.

Kesuma, D., Triatna, C., \& Permana, J. (2011). Pendidikan Karakter: Kajian Teori dan Praktik di Sekolah. Remaja Rosdakarya Offset.

Koni, S. M. (2016). Pengaruh Jejaring Sosial Terhadap Pendidikan Karakter Peserta Didik. TADBIR:Jurnal Manajemen Pendidikan Islam, 4(2), 37-43.

Marhadi, S. K. (2019). Pengantar Geografi Regional. Penerbit ombak.

Miles, M. B., \& Huberman, A. M. (1994). Qualitative data analysis: An expanded sourcebook ( $2 r d, e d)$ (2rd ed.). Sage Publication.

Moleong, L. J. (2007). Metodologi Penelitian Kualitatif. PT. Remaja Rosdakarya.

Munawar, S. A. H. A., \& Halim, A. (2005). Fikih Hubungan Antar Agama. Ciputat Press.

Nieto, S. (2002). Language, Culture, and Teaching. Lawrence Earlbaum Associates Publishers.

Rahmawati, K., \& Fatmawati, L. (2016). Penanaman Karakter Toleransi di Sekolah Dasar Inklusi Melalui Pembelajaran Berbasis Multikultural. 10.

Sapendi, S. (2015). Internalisasi Nilai-nilai Multikultural dalam Pembelajaran Pendidikan Agama Islam di Sekolah (Pendidikan Tanpa Kekerasan). Raheema, 2(1). https://doi.org/10.24260/raheema.v2i1.172

Mania, S. (2010). Implementasi Pendidikan Multikultural dalam Pembelajaran. Lentera Pendidikan: Jurnal Ilmu Tarbiyah dan Keguruan, 13(1), 78-91. https://doi.org/10.24252/lp.2010v13n1a6 
Wajdi, F. (2010). Pendidikan Karakter Dalam Islam: Kajian Al-Qur'an dan Hadis. Jurnal Studi Al-Quran, VI(I).

Wibowo, P. (2010). Tionghoa Dalam Keberagaman Indonesia: Sebuah Perspektif Historis Tentang Posisi dan Identitas. 18.

Yulianti, S. D., Djatmika, E. T., \& Susanto, A. (2016). Pendidikan Karakter Kerja Sama Dalam Pembelajaran Siswa Sekolah Dasar Pada Kurikulum 2013. Jurnal Teori dan Praksis Pembelajaran IPS, 1(1), 33-38. https://doi.org/10.17977/um022v1i12016p033 